\title{
Synthesis and Correlation of Aggregation and Antimicrobial Properties of Homochiral Quaternary Ammonium Bromides Derived from Camphoric Acid
}

${ }^{1}$ Department of Chemical Theory of Drugs, Faculty of Pharmacy, Comenius University, Odbojárov 10, 83232 Bratislava, Slovak Republic

Received 25 November, 2020, accepted 12 February, 202

Abstract A group of homochiral quaternary ammonium salts bearing hydrophobic camphoric acid-derived moiety was synthesized and characterized. The aggregation properties of the prepared compounds were evaluated by surface tension measurements, and the critical micelle concentration (CMC) was calculated. The novel quaternary ammonium bromides were tested as antimicrobial and antifungal agents, and their minimal inhibitory concentration (MIC) was evaluated and compared to clinically used benzalkonium bromide (BAB). Correlation of MIC with CMC reveals that monomers of prepared cationic surfactants, instead of micelles, are primarily responsible for antimicrobial activity.

Keywords quaternary ammonium salts - antimicrobial activity-camphoric acid-critical micelle concentration

\section{INTRODUCTION}

Quaternary ammonium salts (QASs) have found practical applications in many fields such as textile finishes (excellent fabric softeners), antielectrostatic agents and wood preservatives (Bureš, 2019; Gilbert \& Moore, 2005, Kim \& Sun, 2002, Piętka-Ottlik et al., 2012), catalysts (Shirakawa et al., 2012, Brak \& Jacobsen, 2013), ionic liquids (Truong et al., 2012, Morel et al., 2013). Since it was found that cationic lipids, known as cytofectins, are efficient for delivering functional genes (Brigham et al., 1989), the use of cationic surfactants for mediating DNA transfection has increased (Sajomsang et al., 2013, Zhi et al., 2012, Cortesi et al., 2012). QAS with at least one long, hydrophobic chain attached to positively charged nitrogen belongs to the group of cationic surfactants (Rosen 1989). These salts possess properties such as adsorption at interfaces and self-aggregation in the bulk phase. In addition, the QASs with long alkyl chain show a strong biological activity against a broad range of microorganisms such as bacteria (both G+ and G-) and fungi (Lukáč et al., 2010; Mikláš et al., 2012, 2014; Soukup et al., 2020), certain viruses (Soukup et al., 2020; Wong et al., 2002), not excluding SARS-CoV (Schrank et al., 2020), anticancer agents (Kaushik et al., 2012), and many others.

The attraction of cationic surfactants for a negatively charged bacteria surface gives them the ability to intercalate into phospholipid membranes, thus causing the leakage of intercellular materials into the environment and cell death (Devínsky et al., 1985; Kopecká-Leitmanová et al., 1989; Mlynarčík et al., 1981). The disruption of membrane, and subsequent solubilization of its interior, plays an essential role in the mode of antimicrobial action of cationic surfactants and firmly depends on the ability of surfactant molecules to form micelles. Whereas micellization properties are linearly related to the length of the alkyl chains of cationic surfactant, the antimicrobial activity also depends on the number of carbon atoms in the long alkyl chain of surfactant molecule (Marek et al., 2018). The optimal antimicrobial activity for gram-positive bacteria is achieved when the carbon chain length is C12-C14, while for gram-negative bacteria, the highest activity is obtained for the chain length of C14-C16 (Feder-Kubis \& Tomczuk 2013; Pernak and Skrzypczak, 1996; Thebault et al., 2009). Molecules with $n$-alkyl chain length below $\mathrm{C} 4$ and above $\mathrm{C} 18$ are antimicrobially ineffective. In the series of structurally related QASs, the antimicrobial activity increases with the growing chain length until it reaches the maximum. From this point, with a continuous growing chain length, the antimicrobial activity starts to decrease. This phenomenon, called cut-off effect, is typical for many of the biologically active compounds, and it can be caused by many

*E-mail:miklas@fpharm.uniba.sk

○ Open Access. ๑ 2021 European Pharmaceutical Journal, published by Sciendo. (cc) BY-NC-ND This work is licensed under the Creative Commons Attribution-NonCommercialNoDerivatives 3.0 License. 


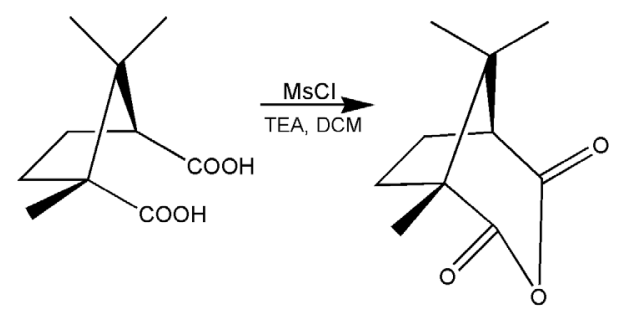

3

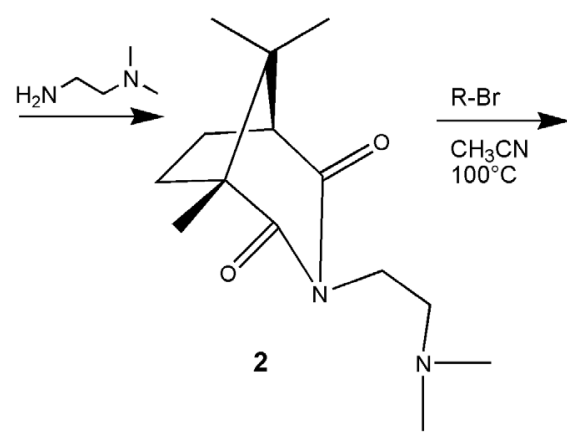

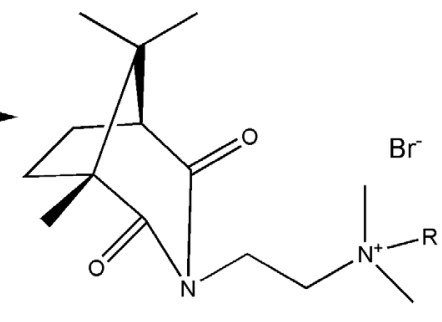

1a $R=$ dodecyl
1b $R=$ tetradecyl
1c $R=$ hexadecyl
1d $R=$ octadecyl

Figure 1. Synthesis of QASs derived from (1R,3S)-(+)-camphoric acid.

reasons (limited aqueous solubility, kinetic effects, interaction with lipid bilayers or proteins) (Balgavý \& Devínsky, 1996).

The alkyl chain length is not the only factor affecting the antimicrobial activity of QASs. The other hydrophobic groups in the molecule of surfactant also influence the aggregation properties, so they can also affect the biological activity. The study of this effect on antimicrobial properties could help in the development of new active QASs (Benkova et al., 2019; Malinak et al., 2014).

In addition, introduction of new structural motives such as heteroatoms or aromatics (Semenov et al., 2011; Pernak et al., 2001) may result in potential antimicrobial agents with higher biological activities, and they could even conquer the growing resistance phenomenon (Jennings 2015). As long as essential oils containing bicyclical camphor or borneol moiety exhibit antibacterial effect (Ruiz-Navajas et al., 2012; Miguel et al., 2011), we decided to design and synthesize QASs bearing hydrophobic bicyclic moiety, hoping that incorporation of two important antimicrobially active structures in one compound will improve their bioactivity. In this study, we have prepared, as illustrated in Fig. 1, three new optically active amphiphilic QASs starting from $(1 R, 3 S)$ (+)-camphoric acid. The aggregation properties of prepared surfactants were studied by tensiometry and critical micelle concentration $(C M C)$; surface tension at $C M C\left(\gamma_{C M C}\right)$ and efficiency of adsorption at the surface $\left(\mathrm{pC}_{20}\right)$ were calculated for each compound from a break in the plot of logarithm of surfactant's concentration versus surface tension. Their antimicrobial activity was tested against gram-negative bacteria Escherichia coli, gram-positive human pathogenic bacteria Staphylococcus aureus, and human fungal pathogen Candida albicans.

\section{EXPERIMENTAL}

\section{Materials and methods}

All compounds used ((1R,3S)-(+)-camphoric acid, methanesulfonyl chloride $(\mathrm{MsCl})$, triethylamine (TEA), $\mathrm{N}, \mathrm{N}$ dimethylethane-1,2-diamine, acetone, dichloromethane (DCM), ethyl acetate, bromoalkanes) are commercially available. DCM was pre-dried over $\mathrm{CaCl}_{2}$ and then distilled from $\mathrm{CaH}_{2}$ under nitrogen atmosphere. ${ }^{1} \mathrm{H}$ and ${ }^{13} \mathrm{C}$ NMR spectra were measured on a Varian Gemini 300 spectrometer at $300 \mathrm{MHz}$ and $75 \mathrm{MHz}$, respectively. Chemical shifts have been reported in ppm relative to an internal reference (TMS). IR spectra were recorded on NICOLET 6700 FT-IR instrument. Polarimetric measurements were obtained using a Jasco P-1010 polarimeter at $589 \mathrm{~nm}$. Elemental analyses were carried out on a Carlo Erba 1108A instrument. All melting points reported were uncorrected and measured on Kofler hot stage. The surface tension measurements were performed on Krüss processor tensiometer K100 (Wilhelmy plate method). The temperature was kept constant at the desired level using thermostatted (Thermo Haake SC100) water bath. Doubledistilled water was used for the preparation of all samples. Measurements of equilibrium surface tension were taken repeatedly until the change in surface tension was less than $0.08 \mathrm{mNm}^{-1}$. The values of surface tension decrease with increasing concentration and the break point provides the CMC value.

\section{Microbiology}

The antimicrobial activity was tested against gram-negative bacteria Escherichia coli CNCTC 377/79, gram-positive bacteria Staphylococcus aureus CNCTC 29/58, and fungi Candida albicans CCM 8186. Solutions of compounds studied were prepared in water (5\%). A suspension of the standard microorganism, prepared from $24 \mathrm{~h}$ cultures of bacteria in blood agar and from $24 \mathrm{~h}$ cultures in the Sabouraud agar for fungi had a concentration of $5 \times 10^{7} \mathrm{cfu} \mathrm{mL}^{-1}$ of bacteria and $5 \times$ $10^{5} \mathrm{cfu} \mathrm{mL}^{-1}$ of Candida. The concentration of microorganisms was determined spectrophotometrically at $540 \mathrm{~nm}$ and adjusted to absorbance $A=0.35$. The microorganism suspension was added to solutions containing the tested compound and to double concentrated peptone broth medium (8\%) for bacteria or Sabouraud medium (12\%) for Candida. The stock solution of the tested compounds was serially diluted by half. The cultures were done in 96-well microliter plates. The microorganisms were incubated for $24 \mathrm{~h}$ at $37^{\circ} \mathrm{C}$, and then, from each well, $5 \mu \mathrm{L}$ of suspension 
Table 1. Characterization of camphoric acid-derived QAS 1.

\begin{tabular}{|c|c|c|c|c|c|c|}
\hline \multirow{2}{*}{ Compound } & \multirow{2}{*}{$\begin{array}{c}\text { Formula / } \\
{[\alpha]_{\mathrm{P}}^{21}} \\
\text { (conc }[\mathrm{g} / 100 \mathrm{~mL}] . \text {, } \\
\text { solvent) }\end{array}$} & \multicolumn{3}{|c|}{$\begin{array}{c}w_{i}(\text { calc. }) / \% \\
w_{i}(\text { found }) / \%\end{array}$} & \multirow{2}{*}{$\begin{array}{c}\text { Yield } \\
\% \\
\end{array}$} & \multirow{2}{*}{$\begin{array}{l}\text { M.p. } \\
{ }^{\circ} \mathrm{C}\end{array}$} \\
\hline & & C & $\mathbf{H}$ & $\mathbf{N}$ & & \\
\hline $1 \mathrm{a}$ & $\begin{aligned} & \mathrm{C}_{26} \mathrm{H}_{49} \mathrm{BrN}_{2} \mathrm{O}_{2} / \\
&+ 7.99\left(0.85, \mathrm{CHCl}_{3}\right) \\
&\end{aligned}$ & 62.2662 .34 & $\begin{array}{l}9.85 \\
9.81 \\
\end{array}$ & 5.585 .61 & 80 & $82-83.5$ \\
\hline $1 b$ & $\begin{array}{c}\mathrm{C}_{28} \mathrm{H}_{53} \mathrm{BrN}_{2} \mathrm{O}_{2} / \\
+6.75\left(0.809, \mathrm{CHCl}_{3}\right) \\
\end{array}$ & 63.5063 .26 & 10.099 .96 & $\begin{array}{l}5.29 \\
5.15 \\
\end{array}$ & 87 & $85-85.5$ \\
\hline 1c & $\begin{array}{c}\mathrm{C}_{30} \mathrm{H}_{55} \mathrm{BrN}_{2} \mathrm{O}_{2} / \\
+7.2\left(\mathrm{C}=0.799, \mathrm{CHCl}_{3}\right) \\
\end{array}$ & $\begin{array}{l}64.61 \\
64.36 \\
\end{array}$ & $\begin{array}{c}10.30 \\
9.96\end{array}$ & $\begin{array}{l}5.02 \\
4.85\end{array}$ & 84 & $95-96.8$ \\
\hline $1 d$ & $\begin{array}{c}\mathrm{C}_{32} \mathrm{H}_{61} \mathrm{BrN}_{2} \mathrm{O}_{2} / \\
+6,7 \mathrm{~d}^{2}\left(\mathrm{c}=0.80, \mathrm{C}^{\prime} \mathrm{HCl}_{3}\right)\end{array}$ & $\begin{array}{l}65.62 \\
65.68\end{array}$ & $\begin{array}{l}10.50 \\
10.45\end{array}$ & $\begin{array}{l}4.78 \\
4.82\end{array}$ & 85 & $96.8-97.5$ \\
\hline
\end{tabular}

were cultured on blood agar (bacteria) or on Sabouraud agar (fungi). After $24 \mathrm{~h}$ at $37^{\circ} \mathrm{C}$, the lowest concentration of QAS that prevented colony formation was determined as minimal inhibitory concentration (MIC). Clinically used benzalkonuim bromide (BAB) was used as a standard.

\section{Synthesis}

1,8,8-trimethyl-3-oxa-bicyclo[3.2.1]octane-2,4-dione (3). (Eagles \& Hitchcock, 2010)

$30 \mathrm{~g}(150 \mathrm{mmol})$ of $(1 R, 3 \mathrm{~S})$-camphoric acid was dissolved in $750 \mathrm{~mL}$ of dry DCM in the argon purged vessel. TEA $(62.6 \mathrm{~mL}$, $450 \mathrm{mmol}, 3$ equiv.) was added to the mixture and stirred to give homogenous solution. Then $\mathrm{MsCl}(11.6 \mathrm{~mL}, 150 \mathrm{mmol})$ was added dropwise for several minutes and allowed to stir overnight. The mixture was transferred to a separatory funnel and washed with $3 \mathrm{M} \mathrm{HCl}(3 \times 100 \mathrm{ml})$ followed by $100 \mathrm{~mL}$ of brine. The organic phase was dried over anhydrous $\mathrm{Na}_{2} \mathrm{SO}_{4^{\prime}}$ and the solvents were removed on rotary evaporator to give yellow crystals. Recrystallization from ethyl acetate gave 20.2 $\mathrm{g}(74 \%)$ of white needles. M.p. $=223-225^{\circ} \mathrm{C} ;[\mathrm{a}]_{D}{ }^{21}=-0.99(1.0$, $\mathrm{CHCl}_{3}$ ). Spectral data were in agreement with the literature (Eagles \& Hitchcock, 2010).

3-(2-(dimethylamino)ethyl)-1,8,8-trimethyl-3-azabicyclo[3.2.1] octane-2,4-dione (2). (Rice \& Grogan, 1957) $20 \mathrm{~g}(0.11 \mathrm{~mol})$ of anhydride 3 and $12.1 \mathrm{~mL}(0.11 \mathrm{~mol})$ of $\mathrm{N}, \mathrm{N}-$ dimethylethane-1,2-diamine were mixed and gently heated $\left(90-100^{\circ} \mathrm{C}\right)$ until a clear reaction mixture was obtained. The resulting partially reacted mass was heated to a temperature of $180^{\circ} \mathrm{C}$ and maintained at that temperature for $7 \mathrm{~h}$. Reaction mixture was allowed to cool, and the resulting oil was vacuum distilled. The fraction distilled at $165-168^{\circ} \mathrm{C} / 10 \mathrm{mmHg}$ was identified as a final product which was obtained in $94 \%$ yield as colorless oil. Spectral data were in agreement with the literature (Rice \& Grogan, 1957).

\section{General procedure for the synthesis of QAS 1}

$8 \mathrm{mmol}$ of imide 2 was dissolved in $15 \mathrm{~mL}$ of acetonitrile. To this solution was added $9.6 \mathrm{mmol}$ (1.2 eqiv.) of bromoalkene, and the reaction mixture was heated at $100^{\circ} \mathrm{C}$ for $24 \mathrm{~h}$. After the reaction, the mixture was allowed to cool, and the solvent was removed by rotary evaporation. To the resulting mixture, orange oil was added $40 \mathrm{~mL}$ of anhydrous benzene, and again, it was evaporated. This procedure was repeated three times. The resulting material, solidified by cooling, was repeatedly crystallized from acetone/hexane mixture, filtered, washed with anhydrous diethyl ether, and dried in vacuum to afford final salts $\mathbf{1}$. Structural and spectral characterization of prepared QASs are summarized in the Table 1 and Table 2.

\section{RESULTS AND DISCUSSION}

Enantiopure QASs of the compounds in series 1 were synthesized, as illustrated in Fig. 1, starting from $(1 R, 3 S)-(+)-$ camphoric acid. In the first step of the synthesis, $(1 R, 3 S)-(+)-$ camphoric acid was dehydrated using $\mathrm{MsCl}$ to yield anhydride 3 (Eagles \& Hitchcock, 2010). The prepared anhydride $\mathbf{3}$ was subsequently heated with $\mathrm{N}, \mathrm{N}$-dimethylethane-1,2-diamine (Rice \& Grogan, 1957). This nucleophilic attack followed by dehydration at $180^{\circ} \mathrm{C}$ gives as a product $N$-substituted imide of camphoric acid 2. The final step of the synthesis was nucleophilic substitution of bromide in bromoalkanes by tertiary amino group of derivative $\mathbf{2}$. QASs $\mathbf{1}$ were isolated after several crystallizations from acetone/hexane mixture as white solids in the yields $80-87 \%$. All of the prepared QASs 1 were identified and characterized thoroughly from spectral and analytical data summarized in Table 1 and Table 2.

The antimicrobial activities of synthesized QASs were determined as a MIC, $\left[\mu \mathrm{mol} \mathrm{I} \mathrm{I}^{-1}\right.$ ] against the gram-positive human pathogenic bacteria S. aureus, gram-negative bacteria E. coli, and human fungal pathogen C. albicans, the values for which are given in Table 3. The MIC values were determined as lowest concentration of the salts $\mathbf{1}$ that completely prevented visible colony formation. All the compounds were dissolved in water for biological evaluation. Clinically used BAB was used as a standard.

According to the results, it can be observed that all of the synthesized QASs exhibit growth inhibition effect against 
Table 2. Spectroscopic data of camphoric acid-derived QASs 1.

\begin{tabular}{|c|c|}
\hline Compound & Spectral data \\
\hline $1 \mathrm{a}$ & 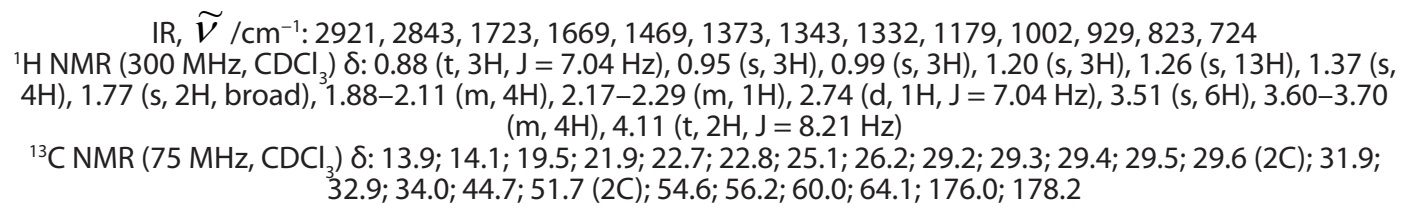 \\
\hline $1 b$ & 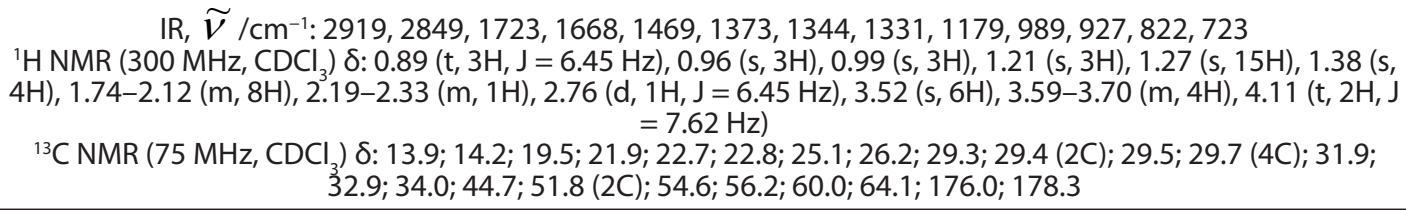 \\
\hline $1 \mathrm{c}$ & $\begin{array}{r}\text { IR, } \widetilde{V} / \mathrm{cm}^{-1}: 2918,2849,1723,1669,1469,1373,1344,1331,1179,990,925,820,722 \\
{ }^{1} \mathrm{H} \mathrm{NMR}\left(300 \mathrm{MHz}, \mathrm{CDCl}_{3}\right) \delta: 0.88(\mathrm{t}, 3 \mathrm{H}, \mathrm{J}=6.45 \mathrm{~Hz}), 0.95(\mathrm{~s}, 3 \mathrm{H}), 0.99(\mathrm{~s}, 3 \mathrm{H}), 1.20(\mathrm{~s}, 3 \mathrm{H}), 1.25(\mathrm{~s}, 21 \mathrm{H}), 1.37(\mathrm{~s}, \\
\text { 4H), } 1.77(\mathrm{~s}, 2 \mathrm{H}, \mathrm{broad}), 1.85-2.11(\mathrm{~m}, 4 \mathrm{H}), 2.17-2.30(\mathrm{~m}, 1 \mathrm{H}), 2.75(\mathrm{~d}, 1 \mathrm{H}, \mathrm{J}=6.45 \mathrm{~Hz}), 3.51(\mathrm{~s}, 6 \mathrm{H}), 3.56-3.70 \\
(\mathrm{~m}, 4 \mathrm{H}), 4.11(\mathrm{t}, 2 \mathrm{H}, \mathrm{J}=7.62 \mathrm{~Hz}) \\
{ }^{13} \mathrm{C} \mathrm{NMR}\left(75 \mathrm{MHz}, \mathrm{CDCl}_{3}\right) \delta: 13.9 ; 14.1 ; 19.5 ; 21.9 ; 22.7 ; 22.8 ; 25.1 ; 26.2 ; 29.3 ; 29.4(2 \mathrm{C}) ; 29.5 ; 29.7(6 \mathrm{C}) ; 31.9 ; \\
32.9 ; 34.0 ; 44.6 ; 51.7(2 \mathrm{C}) ; 54.5 ; 56.2 ; 60.0 ; 64.1 ; 176.0 ; 178.2\end{array}$ \\
\hline $1 d$ & 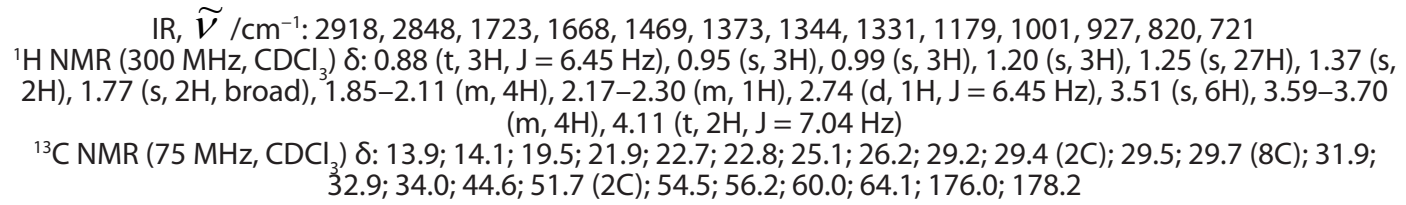 \\
\hline
\end{tabular}

Table 3. Minimal inhibitory concentrations $\left[\mu \mathrm{mol}^{-1}\right]$ of prepared QAS 1.

\begin{tabular}{|c|c|c|c|}
\hline Compound & $\begin{array}{c}\text { S. aureus } \\
\text { CNCTC 29/58 }\end{array}$ & $\begin{array}{c}\text { E. coli } \\
\text { CNCTC 377/79N }\end{array}$ & $\begin{array}{c}\text { C. albicans } \\
\text { CCM 8186 }\end{array}$ \\
\hline 1a & 6.1 & 24.3 & 12.2 \\
\hline 1b & 0.7 & 5.8 & 0.7 \\
\hline 1c & 0.6 & 5.5 & 0.6 \\
\hline 1d & 324.1 & 665.8 & 324.1 \\
\hline BAB & 26 & 260 & 26 \\
\hline
\end{tabular}

all three types of microbes, with higher efficiency against $S$. aureus and C. albicans (Table 3). Gram-negative E. coli was found to be most resistant to the prepared salts among the tested microorganisms. This is presumably due to the cell membrane composition. Gram-negative bacteria contain an outer membrane with an external component that consists mainly of lipopolysaccharides, which acts as a barrier and prevents antimicrobial agents and biocides from entering the cell (Pérez et al., 2009).

The main target site of QASs is the cytoplasmic membrane comprised of a phospholipid bilayer. QASs are able to insert into the phospholipid bilayer, which is accompanied by membrane disorganization and structural and functional changes in the cell membrane, inducing leakage of intracellular components (Gilbert and Moore, 2005). In addition, QASs were also found to inhibit ATP synthesis by neutralizing the proton motive force (PMF) (Denyer \& Hugo, 1977). The PMF is initiated by a proton gradient across the cytoplasmic membrane and is responsible for many respiratory and photosynthetic processes, including ATP synthesis. As long as QASs are surface active agents, they can cause denaturation of proteins anchored in the cytoplasmic membrane or dissociation of an enzyme from its prosthetic group. Because this effect was observed at concentrations much higher than lethal ones, the enzyme inhibition is not the primary injury caused by cationic surfactants (Merianos 1991). If we take a deeper look into the mechanism of action of QASs, for the most of them, no specific target site has been recognized. However, it is not excluded that there can exist some target specificities, like DNA binding, as shown by 


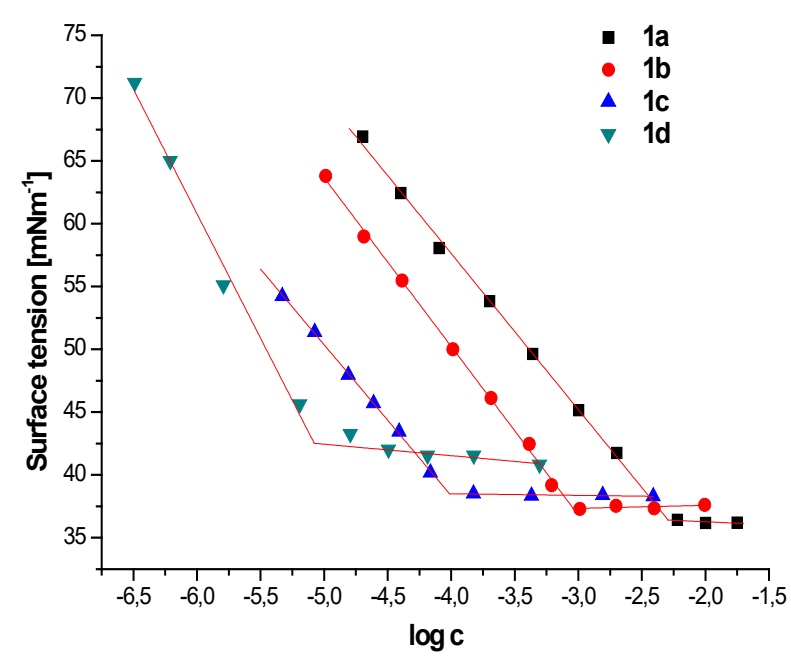

Figure 2. Surface tension versus the logarithm of the aqueous molar concentration of $1 a-1 d$ at $25^{\circ} \mathrm{C}$.

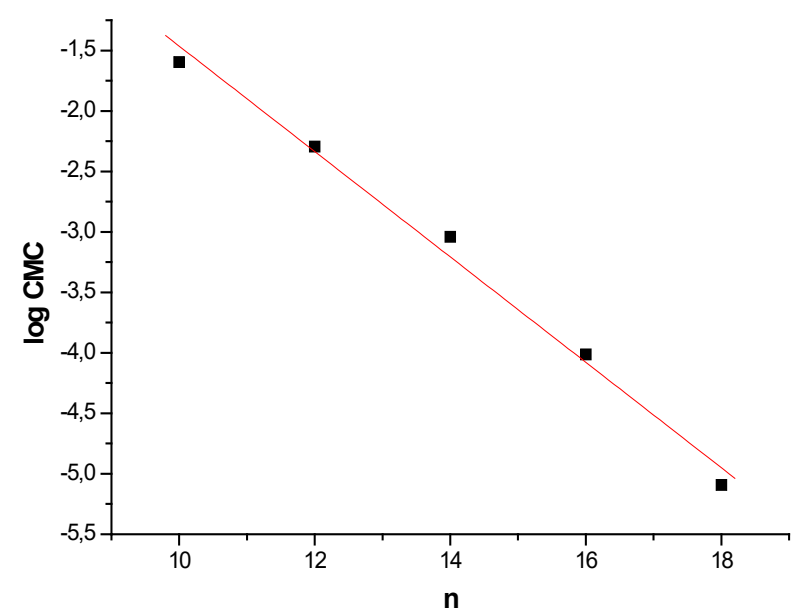

Figure 3. Variation of $\log C M C$ with chain length of $1 a-1 d$ at $25^{\circ} \mathrm{C}$.

Menzel (2011) and Zhang (2013), because the antimicrobial activity of QASs changes significantly against various types of microorganisms and explanation only by the cationic charge and hydrophobic tail cannot be used.

The antimicrobial activity of surfactants generally depends on the alkyl chain length, although this correlation is not linear. In the series of prepared QASs $\mathbf{1} \mathbf{a}-\mathbf{1} \mathbf{d}$, maximum antimicrobial activity was observed for compound 1c with 16 carbon atoms in alkyl chain, though salt $\mathbf{1} \mathbf{b}$ with 14 carbon atoms in alkyl chain exhibits the similar antimicrobial activity. It is noteworthy that among the salts examined in this study, all of the prepared QASs inhibited the growth of microorganisms at the concentrations lower than clinically used BAB.

QASs 1a-1d exhibit surface activities such as surface tension lowering and micelle formation. The surface properties of prepared QASs were investigated by surface tension
Table 4. $C M C, g(C M C)$ and $p C_{20}$ values of prepared QASs calculated from tensiometry measurements.

\begin{tabular}{|c|c|c|c|c|}
\hline & $\mathbf{1 a}$ & $\mathbf{1 b}$ & $\mathbf{1 c}$ & $\mathbf{1 d}$ \\
\hline $\begin{array}{c}\mathrm{CMC} \\
{\left[\mathrm{molL}^{-1}\right]}\end{array}$ & $\begin{array}{c}5.07 \times 10^{-3} \\
\pm 0.23 \times 10^{-3}\end{array}$ & $\begin{array}{c}9.13 \times 10^{-4} \\
\pm 0.98 \times 10^{-4}\end{array}$ & $\begin{array}{c}0.97 \times 10^{-4} \\
\pm 0.05 \times 10^{-4}\end{array}$ & $\begin{array}{c}8.09 \times 10^{-6} \\
\pm 1.13 \times 10^{-6}\end{array}$ \\
\hline $\begin{array}{c}\mathrm{Y}_{(\mathrm{CMC})} \\
{\left[\mathrm{mNm}^{-1}\right]}\end{array}$ & 36.36 & 37.32 & 38.49 & 42.51 \\
\hline $\mathrm{pC}_{20}$ & 3.5 & 4.1 & 5.1 & 5.5 \\
\hline
\end{tabular}

measurements. The plots of surface tension against the logarithm of surfactant's concentration are presented in Fig. 2. $C M C$, surface tension at $C M C\left(\gamma_{C M C}\right)$, and efficiency of adsorption at the surface $\left(\mathrm{pC}_{20}\right)\left(\mathrm{pC}_{20}\right.$ - the negative log of $\mathrm{C}_{20^{\prime}}$ the surfactant molar concentration required to reduce surface tension by $20 \mathrm{mNm}^{-1}$ ) of QASs were calculated from the break in the plots and are shown in Table 4.

The surfactant concentration required to reduce the surface tension of pure water by $20 \mathrm{mNm}^{-1}$ was used to compare the efficiency of surfactant $\left(\mathrm{pC}_{20}\right)$. Higher values indicate that the surfactant adsorbs at the interface more efficiently. The values of $\mathrm{pC}_{20}$ in Table 4 show that with increasing alkyl chain length the $\mathrm{pC}_{20}$ increases. This means that better reduction in surface tension is achieved for surfactants with longer alkyl chain used at a smaller concentration. It is known that by increasing the alkyl chain length of a surfactant the CMC values decrease (Rosen 1989). It can be seen from Fig. 3 that values of the log CMC decrease linearly with number of carbon atoms in the chain from $\mathbf{1 a}$ to $\mathbf{1 d}$. This linear relationship between chain length and CMC for homologous series of surfactants is known as Kleven's equation: $\log C M C=A-B n$, where $n$ is the number of carbon atoms in the long alkyl chain and $A$ and B are constants (Klevens, 1953). For prepared QASs 1, the linear relationship was found to be $\log C M C=2.89-0.43 n$. The surface tension at $C M C$ values $\left(\gamma_{C M C}\right)$ are in the range of 36.36-42.51 $\mathrm{mNm}^{-1}$.

With regard to better understanding of the relation between the antimicrobial activities and micelle forming ability, the MIC values [mmolL $\left.{ }^{-1}\right]$ of the prepared QASs were correlated with their CMC values [mmolL-1] (Fig. 4). As seen, the CMC curve intersects the MIC curve at the cut-off point (16 carbon atoms chain length) for all the microorganisms tested. In addition, MICs of the prepared cationic surfactants with the alkyl chain length shorter than 16 carbon atoms were found below the CMCs, while above the cut-off point, the MICs appear above the CMC. A similar behavior was observed also in the study of cationic surfactants derived from amino acids (Joondan et al., 2014), alkyl betaines, and $\mathrm{N}$-oxides (Birnie et al. 2000). This observation could be explained according to Joondan et al. that at the concentration under the CMC, the surfactant molecules are soluble; therefore, monomers predominate and participate in the interaction 
a)

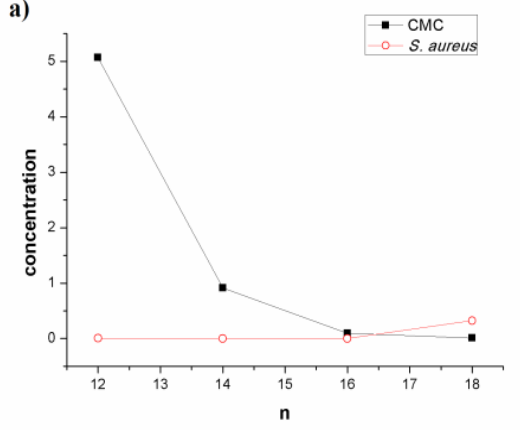

b)

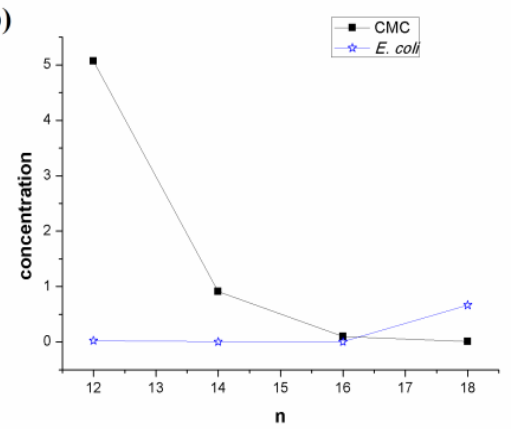

c)

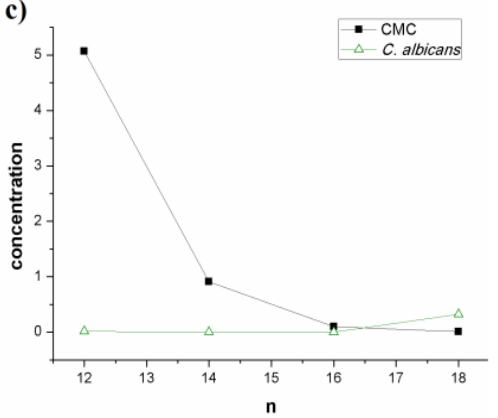

Figure 4. Correlation of CMC $\left[\mathrm{mmolL}^{-1}\right]$ and MIC $\left[\mathrm{mmoll}^{-1}\right]$ of QASs 1a-1d for a) S. aureus; b) E. coli; c) C. albicans.

with phospholipid bilayer in the bacterial cell wall. On the contrary, molecules with longer chain length aggregate into the micelles at much lower concentration, thus decreasing the concentration of monomers. To achieve bactericidal effect, the higher concentration of the surfactant is needed (Joondan et al., 2014).

\section{CONCLUSIONS}

In summary, we have designed and synthesized a new amphiphilic ammonium salt that could be classified as potential antimicrobials. All of the prepared QASs showed higher antimicrobial activity on gram-positive bacteria and fungi than on gram-negative strain. The maximum antimicrobial activity was observed for compound 1c with
16 carbon atoms in alkyl chain. QASs $\mathbf{1 a - 1 c}$ exhibit higher antimicrobial and antifungal activity than clinically used $B A B$. Aggregation parameters like $C M C, \gamma_{C M C^{\prime}} \mathrm{pC}_{20}$ of synthesized cationic surfactants $\mathbf{1 a - 1 d}$ were studied by tensiometry, and based on the correlation between CMC and MIC, we can conclude that monomers of surfactants are mainly responsible for antimicrobial activity.

\section{ACKNOWLEDGMENT}

Financial support of this work by the Ministry of Education, Science, Research, and Sport of the Slovak Republic under the contract No VEGA-1/0145/20 is gratefully acknowledged by the authors.

\section{References}

[1] Balgavý P. Devínsky F. Cut-off effects in biological activities of surfactants. Adv Colloid Interface Sci. 1996;66:23-63.

[2] Benkova M. Soukup O. Prchal L. et al. Synthesis, antimicrobial effect and lipophilicity-activity dependence of three series of dichained N-alkylammonium salts. Chemistry 2019;4:12076-12084.

[3] Birnie CR. Malamud D. Schnaare RL. Antimicrobial evaluation of $\mathrm{N}$-alkyl betaines and $\mathrm{N}$-alkyl- $\mathrm{N}, \mathrm{N}$-dimethylamine oxides with variations in chain length. Antimicrob Agents Chemother. 2000;44:2514-2517.

[4] Brak K. Jacobsen EN. Asymmetric ion-pairing catalysis. Angew Chem Int Ed. 2013;52(2):534-561.

[5] Brigham KL. Mezrick B. Christman B. Magnuson M. King G. Berry LC. In vivo Transfection of Murine Lungs with a Functioning Prokaryotic Gene Using a Liposome Vehicle. Am J Med Sci. 1989; 298: 278-281.

[6] Bureš F. Quaternary Ammonium Compounds: Simple in Structure, Complex in Application. Top Curr Chem. 2019;377:14.

[7] Cortesi R. Bergamini P. Ravani L. et al. Long-chain cationic derivatives of PTA (1,3,5-triaza-7-phosphaadamantane) as new components of potential non-viral vectors. Int J Pharm. 2012; 431:176-182.
[8] Denyer SP Hugo WB. The mode of action of cetyltrimethylammonium bromide (CTAB) on Staphylococcus aureus. J Pharm Pharmacol. 1977;29:66P.

[9] Devínsky F. Lacko I. Mlynarčík D. Račanský V. Krasnec L. Relationship between critical micelle concentrations and minimum inhibitory concentrations for some non-aromatic quaternary ammonium salts and amine oxides. Tenside Deterg. 1985;22:10-15.

[10] Eagles JB. Hitchcock SR. Synthesis of D-camphor based $\mathrm{Y}$-amino acid (1S,3R)-3-amino-2,2,3-trimethylcyclopentane carboxylic acid. Tetrahedron: Asymmetry. 2010;21(5):519-523.

[11] Feder-Kubis J. Tomczuk K. The effect of the cationic structures of chiral ionic liquids on their antimicrobial activities. Tetrahedron 2013;69(21):4190-4198.

[12] Gilbert P. Moore LE. Cationic antiseptics: diversity of action under a common Epithet. J. Appl Microbiol 2005; 99: 703-715.

[13] Jennings MC. Minbiole KPC. Wuest WM. Quaternary Ammonium Compounds: An Antimicrobial Mainstay and Platform for Innovation to Address Bacterial Resistance. ACS Infect Dis. 2015;1:288-303.

[14] Joondan N. Jhaumeer-Laulloo S. Caumul P. A study of the antibacterial activity of L-Phenylalanine and L-Tyrosine esters in 
relation to their CMCs and their interactions with 1,2-dipalmitoylsn-glycero-3-phosphocholine, DPPC as model membrane. Microbiol Res. 2014;169:657-685.

[15] Kaushik NK, Attri P, Kaushik N, Choi EH. Synthesis and Antiproliferative Activity of Ammonium and Imidazolium Ionic Liquids against T98G Brain Cancer Cells. Molecules 2012;17(12):13727-13739.

[16] Kim YH. Sun G. Functional Finishing of Acrylic and Cationic Dyeable Fabrics: Intermolecular Interactions. Text Res J. 2002; 72: 1052-1056.

[17] Klevens HB. Structure and aggregation in divte solutions of surface aktive agents. J Am Oil Chem Soc. 1953;30:74-80.

[18] Kopecká-Leitmanová A. Devinsky F. Mlynarčík D. Lacko I. Interaction of amine oxides and quaternary ammonium salts with membrane and membrane-associated processes in E. Coli cells: mode of action. Drug Metabol Drug Interact. 1989;7(1):29-51.

[19] Lukáč M, Lacko I, Bukovský M et al. Synthesis and antimicrobial activity of a series of optically active quaternary ammonium salts derived from phenylalanine. Cent Eur J Chem. 2010;8:194-201.

[20] Malinak D. Dolezal R. Marek J. et al. 6-Hydroxyquinolinium salts differing in the length of alkyl side-chain: synthesis and antimicrobial activity. Bioorg Med Chem Lett. 2014;24:5238-5241.

[21] Marek J. Joskova V. Dolezal R. et al. Synthesis, antimicrobial effect and surface properties of hydroxymethyl-substituted pyridinium salts. Lett Drug Des Discov. 2018;15:828-842.

[22] Menzel TM. Tischer M. Francois P. et al. Mode-of-Action studies of the Novel Bisquaternary Bisnaphthalimide MT02 against Staphylococcus aureus. Antimicrob Agents Chemother. 2011;55:311-320.

[23] Merianos JJ. Quaternary ammonium antimicrobial compounds. In Disinfection, sterilization, and preservation, $4^{\text {th }}$ Edition, 1991, Lea \& Febiger, Philadelphia. ISBN: 0-8121-1364-0.

[24] Miguel G. Cruz C. Faleiro ML. Simoes MTF. Figueiredo AC. Barroso JG. Pedro LG. Salvia officinalis L. essential oils: effect of hydrodistillation time on the chemical composition, antioxidant and antimicrobial activities. Nat Prod Res. 2011;25(5):526-541.

[25] Mikláš R, Miklášová N, Bukovský M, Devínsky F. Synthesis and antimicrobial properties of binaphthyl derived quaternary ammonium bromides. Acta Facult Pharm Univ Comenianae. 2012;59:39-47.

[26] Mikláš R, Miklášová N, Bukovský M, Horváth B, Kubincová J, Devínsky F. Synthesis, surface and antimicrobial properties of some quaternary ammonium homochiral camphor sulfonamides. Eur J Pharm Sci. 2014;65:29-37.

[27] Mlynarčík D. Denyer SP. Hugo WB. A study of the action of a bisquaternary ammonium salt, an amine oxide and an alkoxy phenylcarbamic acid ester on some metabolic functions in Staphylococcus aureus. Microbios 1981;30:27-35.

[28] Morel A. Silarska E. Trzeciak A M. Pernak J. Palladium-catalyzed asymmetric Heck arylation of 2,3-dihydrofuran - effect of prolinate salts. Dalton Trans. 2013; 42(4): 1215-1222.

[29] Pérez L. Pinazo A. García MT et al. Cationic surfactants from lysine: Synthesis, micellization and biological evaluation. Eur J Med Chem. 2009;44:1884-1892.

[30] Pernak J. Skrzypczak A. 3-Alkylthiomethyl-1-ethylimidazolium chlorides. Correlation between critical micelle concentrations and minimum inhibitory concentrations. Eur J Med Chem. 1996;31:901-903.

[31] Pernak J. Kalewska J. Ksycińska H. Cybulski J. Synthesis and antimicrobial activities of some pyridinium salts with alkoxymethyl hydrophobic group. Eur J Med Chem. 2001;36:899-907.

[32] Piętka-Ottlik M. , Frąckowiak R., Maliszewska I., Kołwzan B., Wilk KA. Ecotoxicity and biodegradability of antielectrostatic dicephalic cationic surfactants. Chemosphere 2012; 89: 11031111.

[33] Rice LM. Grogan CH. Hypotensive agents VI. Substitued 3-Azabicyclo[3.2.1]octane derivates. J Org Chem. 1957;22:185189.

[34] Rosen MJ. Surfactants and interfacial phenomena, $2^{\text {nd }}$ Edition, New York, John Wiley \& Sons. ISBN: 0-471-83651-6; 1989.

[35] Ruiz-Navajas Y. Viuda-Martos M. Sendra M. Perez-Alvarez JA. Fernandez-Lopez J. Chemical characterization and antibacterial activity of Thymus moroderi and Thymus piperella essential oils, two Thymus endemic species from southeast of Spain. Food Control 2012;27(2):294-299.

[36] Sajomsang W. Gonil P. Ruktanonchai UR. Petchsangsai M. Opanasopit P. Puttipipatkhachorn S. Effects of molecular weight and pyridinium moiety on water-soluble chitosan derivatives for mediated gene delivery. Carbohydr Polym. 2013; 91(2): 508-517.

[37] Schrank CL. Minbiole KPC. Wuest WM. Are Quaternary Ammonium Compounds, the Workhorse Disinfectants, effective against Severe Acute Respiratory Syndrome-Coronavirus-2? ACS Infect Dis. 2020;6(7):1553-1557.

[38] Semenov VE. Mikhailov AS. Voloshina AD. Et al. Antimicrobial activity of pyrimidinophanes with thiocytosine and uracil moieties. Eur J Med Chem 2011;46(9):4715-4724.

[39] Shirakawa S. Liu K. Maruoka K. Catalytic Asymmetric Synthesis of Axially Chiral o-lodoanilides by Phase-Transfer Catalyzed Alkylations. J Am Chem Soc. 2012; 134(2): 916-919.

[40] Soukup O. Benkova M. Dolezal R. et al. The wide-spectrum antimicrobial effect of novel $\mathrm{N}$-alkyl monoquaternary amonium salts and their mixtures; the QSAR study against bakteria. Eur J Med Chem. 2020;206:112584.

[41] Thebault P. de Givenchi ET. Levy R. Vandenberghe Y. Guittard F. Géribaldi S. Preparation and antimicrobial behaviour of quaternary ammonium thiol derivatives able to be grafted on metal surfaces. Eur J Med Chem. 2009;44:717-724.

[42] Truong TKT. Olivier NVB. Aupoix A. Pegot B. Vo-Thanh G. Chiral Ionic Liquids Derived from (-)-Ephedrine and Carbohydrates: Synthesis, Properties and Applications to Asymmetric Synthesis and Catalysis. Curr Org Synth. 2012; 9(1): 53-64.

[43] Wong Y-L, Hubieki MP, Curfaman CL et al. A Structure-Activity Study of Spermicidal and Anti-HIV Properties of Hydroxylated Cationic Surfactants. Bioorg Med Chem. 2002;10:3599-3608.

[44] Zhang Y. Zhu W. Liu Y-L. et al. Chemo-Immunotherapeutic Antimalarials Targeting Isoprenoid Biosynthesis. ACS Med Chem Lett. 2013;4:423-427.

[45] Zhi DF. Zhang SB. Qureshi F. et al. Synthesis and biological activity of carbamate-linked cationic lipids for gene delivery in vitro. Bioorg Med Chem Lett. 2012; 22(11): 3837-3841. 